\title{
PENDEKATAN DALAM PENGELOLAAN KELAS
}

\author{
Oleh: \\ Dra.Lailatu Zahroh, MPdI ${ }^{1}$
}

\begin{abstract}
ABSTRAK
Kelas merupakan tempat yang dihuni oleh sekelompok manusia dengan berbagi latar belakang, karakter, kepribadian, tingkah laku dan emosi yang berbeda-beda. Jadi pengelolaan kelas bukanlah masalah yang berdiri sendiri, tetapi terkait dengan berbagai factor. Permasalahan peserta didik adalah factor utama yang terkait langsung dalam hal ini. Karena pengelolaan kelas yang dilakukan guru tidak lain adalah untuk meningkatkan kegairahan belajar peserta didik secara berkelompok maupun secara individual. Lahirnya interaksi yang optimal tentu saja bergantung dari pendekatan yang guru lakukan dalam rangka pengelolaan kelas.
\end{abstract}

Kata Kunci : Pengelolaan Kelas, Pendekatan Pengelolaan Kelas

\section{A. Pendahuluan}

Suatu kondisi belajar yang optimal dapat tercapai jika guru mampu mengatur peserta didik dan sarana pembelajaran serta mengendalikannya dalam suasana yang menyenangkan untuk mencapai tujuan pembelajaran. Juga hubungan interpersonal yang baik antara guru dan peserta didik, peserta didik dengan peserta didik, merupakan syarat keberhasilan pengelolaan kelas. Pengelolaan kelas yang efektif merupakan prasyarat mutlak bagi terjadinya kegiatan pembelajaran yang efektif.

Setiap guru masuk ke dalam kelas, maka pada saat itu pula ia menghadapi dua masalah pokok, yaitu masalah pembelajaran dan masalah manajemen. Jelasnya sebagai berikut:

- Masalah pembelajaran

Adalah usaha membantu peserta didik dalam mencapai tujuan khusus pembelajaran secara langsung, misalnya membuat RPP, penyajian informasi, mengajukan pertanyaan, evaluasi dan masih banyak lagi.

- Masalah manajemen

Adalah usaha untuk menciptakan dan mempertahankan kondisi sedemikian rupa sehingga kegiatan pembelajaran dapat berlangsung secara efektif dan efisien. 
Misalnya, memberi penguatan, mengembangkan hubungan guru-peserta didik, membuat aturan kelompok yang produktif.

Terkadang sukar untuk membedakan mana masalah pembelajaran dan mana masalah manajemen. Masalah pembelajaran harus diatasi dengan cara pembelajaran, dan masalah pengelolaan kelas harus diatasi dengan cara pengelolaan.

Beberapa alasan guru harus melakukan pengelolaan kelas : (1) Mengelola kelas merupakan factor yang dapat menciptakan dan mempertahankan suasana serta kondisi kelas agar selalu tampak efektif, (2) Dengan mengelola kelas yang baik, maka interaksi antara guru dengan peserta didik dapat terjalin dengan baik, (3) Kelas juga menjadi tempat dimana kurikulum pendidikan dengan segala komponennya, materi dengan sumber pelajarannya, serta segala pokok bahasan mengenai materi itu diajarkan dan ditelaah ulang didalam kelas, dan (4) Karena dari hari ke hari, bahkan dari waktu ke waktu, tingkah laku dan perbuatan peserta didik selalu berubah-ubah sesuai dengan pertambahan usia, perkembangan karakter, dan meluasnya pergaulan mereka

Apakah pengelolaan kelas itu, dan apa saja pendekatan dalam pengelolaan kelas yang harus guru lakukan agar pembelajaran menjadi efektif?

\section{B. Pengelolaan Kelas}

\section{Pengertian}

Salah satu tugas guru yang tidak pernah ditinggalkan ialah pengelolaan kelas. Pengelolaan kelas dimaksudkan untuk menciptakan lingkungan belajar yang kondusif bagi peserta didik sehingga tercapai tujuan pembelajaran secara efektif dan efisien. Ketika kelas terganggu, guru berusaha mengembalikannya agar tidak menjadi penghalang bagi kegiatan pembelajaran; menurut .E. Mulyasa,. pengelolaan kelas merupakan keterampilan guru untuk menciptakan iklim pembelajaran yang kondusif, dan mengendalikannya jika terjadi gangguan dalam pembelajaran ${ }^{2}$.

Pengelolaan kelas terdiri dari dua kata yaitu "pengelolaan" dan "kelas". Pengelolaan itu sendiri akar katanya adalah "kelola", ditambah awalan "pe" dan akhiran "an". Istilah lain dari pengelolaan adalah "pengelolaan". Pengelolaan atau pengelolaan dalam pengertian umum adalah pengadministrasian, pengaturan atau 
penataan suatu kegiatan ${ }^{3}$ Pengelolaan adalah system yang berfungsi untuk mengelola sesuatu $^{4}$

Namun secara definisinya para ahli memiliki pengertian sendiri-sendiri dan beragama diantaranya:

a. Menurut SP Siagian dalam buku "Filsafat Administrasi", pengelolaan dapat didefinisikan sebagai kemampuan atau keterampilan untuk memperoleh suatu hasil dalam rangka pencapaian tujuan melalui oranglain

b. Menurut H.Arifin Abdulrachman dalam buku "Kerangka Pokok-pokok Pengelolaan" diartikan sebagai kegiatan /aktivitas, proses yakni kegiatan dalam rentetan urutan-urutan, institute/orang-orang yang melakukan kegiatan atau proses kegiatan

c. Menurut Ordway Tead yang disadur oleh FE Rosyidi dalam buku "Organisasi dan Pengelolaan mendefinisikan proses dan kegiatan pelaksanaan usaha memimpin dan menunjukkan arah penyelenggaraan tugas suatu organisasi di dalam mewujudkan tujuan yang telah ditetapkan

d. Menurut Marry Parker Follet, pengelolaan adalah sebagai seni dalam menyelesaikan pekerjaan melalui orang lain ${ }^{5}$

Suatu kegiatan yang memiliki tujuan tidak akan berjalan dengan baik tanpa adanya pengelolaan yang benar. Tidak adanya pengelolaan yang baik ini dengan sendirinya dapat menghambat tercapainya tujuan yang hendak dicapai. Sedangkan pengertian kelas ada beberapa pendapat, diantaranya:

1) Oemar Hamalik

Kelas adalah suatu kelompok orang yang melakukan kegiatan belajar bersama, yang mendapat pembelajaran dari guru ${ }^{6}$.

3 Suharsimi Arikunto, 1990, Manajemen Pengajaran Secara Manusiawi, Jakarta, Rineka Cipta, hal 2

${ }^{4}$ Syaifurahman, 2013, Manajemen dalam Pembelajaran, Jakarta, PT Indeks, hlm 50

${ }^{5}$ http://carapedia.com, diunduh tanggal 19 September 2013

6 Oemar Hamalik, 1987, Pendekatan Baru Strategi Belajar Mengajar Berdasarkan CBSA, Bandung, Sinar Baru, halaman 311 


\section{2) Suharsimi Arikunto}

Kelas adalah sekelompok siswa yang pada waktu yang sama menerima pelajaran yang sama dari guru yang sama. Dengan batasan pengertian ini maka ada tiga persyaratan untuk dapat terjadinya (kelas) yaitu :

a) Sekelompok anak, walaupun dalam waktu yang sama bersama-sama menerima pelajaran, tetapi jika bukan pelajaran yang sama dari guru yang sama, namanya bukan kelas

b) Sekelompok anak yang dalam waktu yang sama menerima pelajaran yang sama, tetapi dari guru yang berbeda, namanya juga bukan kelas

c) Sekelompok anak yang sama, menerima pelajaran yang sama dari guru yang sama, tetapi jika pelajaran tersebut diberikan secara bergantian, namanya juga bukan kelas ${ }^{7}$

Suharsimi Arikunto menegaskan, bahwa kelas yang dimaksud disini adalah kelas dengan sistem pembelajaran klasikal dalam pembelajaran secara tradisional.

3) Hadlari Nawawi, memandang kelas dari dua sudut, yaitu:

a) Kelas dalam arti sempit, yakni ruangan yang dibatasi oleh empat dinding, tempat sejumlah peserta didik berkumpul untuk mengikuti kegiatan pembelajaran.

Kelas dalam pengertian tradisional ini mengandung sifat statis karena sekedar menunjuk pengelompokan peserta didik menurut tingkat perkembangannya yang antara lain didasarkan pada batas umur kronologis masing-masing

b) Kelas dalam arti luas, adalah suatu masyarakat kecil yang merupakan bagian dari masyarakat sekolah, yang sebagai satu kesatuan diorganisasi menjadi unit kerja yang secara dinamis menyelenggarakan kegiatan pembelajaran yang kreatif untuk mencapai suatu tujuan ${ }^{8}$

Adapun pengertian pengelolaan kelas juga terdapat beberapa pendapat, diantaranya:

\section{1) Made Pidarta}

Pengelolaan kelas ialah proses seleksi dan penggunaan alat-alat yang tepat terhadap problem dan situasi kelas. Ini berarti guru bertugas menciptakan, memperbaiki dan

${ }^{7}$ Suharsimi Arikunto, Op Cit, halaman 67

${ }^{8}$ Hadari Nawawi, 1989, Organisasi Sekolah dan Pengelolaan Kelas, Jakarta, Haji Masagung, halaman 114 
memelihara sistem/organisasi kelas sehingga anak didik dapat memanfaatkan kemampuannya, bakatnya, dan energinya pada tugas-tugas individual $^{9}$

2) Sudirman $N$

Pengelolaan kelas ialah upaya mendayagunakan potensi kelas ${ }^{10}$

3) Hadari Nawawi

Pengelolaan kelas ialah kemampuan guru atau wali kelas dalam mendayagunakan potensi kelas berupa pemberian kesempatan yang seluas-luasnya pada setiap personil untuk melakukan kegiatan yang kreatif dan terarah sehingga waktu dan dana yang tersedia dapat dimanfaatkan secara efisien untuk melakukan kegiatankegiatan kelas yang berkaitan dengan kurikulum dan perkembangan peserta didik ${ }^{11}$

4) Suharsimi Arikunto

Pengelolaan kelas ialah suatu usaha yang dilakukan oleh penanggung jawab kegiatan belajar mengajar atau yang membantu dengan maksud agar dicapai kondisi optimal sehingga dapat terlaksana kegiatan belajar seperti yang diharapkan ${ }^{12}$.

Suharsimi memahami pengelolaan kelas ini dari dua segi yaitu pengelolaan yang menyangkut siswa dan pengelolaan fisik. Menurutnya membuka jendela agar udara segar dapat masuk ke ruangan atau agar ruangan menjadi terang, menyalakan lampu listrik, menggeser papan tulis, mengatur meja merupakan kegiatan pengelolaan upaya kelas fisik.

5) AJE Toenlioe

Pengelolaan kelas adalah usaha guru untuk menciptakan dan mempertahankan kondisi yang memungkinkan kegiatan pengelolaan pembelajaran dapat berlangsung dengan lancar sehingga tujuan pembelajaran dapat tercapai ${ }^{13}$

\footnotetext{
${ }^{9}$ Made Pidarta, tt, Pengelolaan Kelas, Surabaya, Usaha Nasional

${ }^{10}$ Sudirman, 1991, Ilmu Pendidikan, Bandung, Remaja Rosdakarya, halaman 310

${ }^{11}$ Hadari Nawawi, Op Cit, halaman 115

12 Suharsimi Arikunto, 1988,Pengelolaan Kelas dan Siswa Sebuah Pendekatan Evaluatif, Jakarta, Rajawali Press, halaman 67

13 AJE Toenlioe, 1991, Teori dan Praktek Pengelolaan Kelas, Surabaya, Usaha Nasional,
} halaman16 
6) Muljani A Nurhadi

Pengelolaan kelas adalah upaya mengelola siswa di kelas yang dilakukan untuk menciptakan dan mempertahankan suasana (kondisi) kelas yang menunjang program pengajaran dengan jalan menciptakan dan mempertahankan motivasi siswa untuk selalu terlibat dan berperan serta dalam proses pendidikan di sekolah ${ }^{14}$

7) Amatembun

Pengelolaan kelas adalah upaya yang dilakukan oleh guru dalam menciptakan dan mempertahankan serta mengembang tumbuhkan motivasi belajar untuk mencapai tujuan yang telah di tetapkan ${ }^{15}$

\section{8) Usman}

Pengelolaan kelas yang efektif merupakan prasyarat mutlak bagi terjadinya proses belajar mengajar yang efektif ${ }^{16}$.

Pengelolaan dipandang sebagai salah satu aspek penyelenggaraan sistem pembelajaran yang mendasar, di antara sekian macam tugas guru di dalam kelas

Dari uraian dapat dipahami bahwa pengelolaan kelas adalah suatu usaha guru untuk menciptakan suasana kegiatan belajar mengajar yang kondusif agar tercapai kondisi yang optimal sesuai dengan yang diharapkan dan mengendalikannya apabila terjadi gangguan dalam pembelajaran.. Atau dengan kata lain pengelolaan kelas merupakan kegiatan pengaturan kelas untuk kepentingan pembelajaran.

Adapun hubungan antara pengelolaan kelas dengan pengelolaan pembelajaran dalam rangka mencapai tujuan pembelajaran dapat dilihat pada diagram berikut:

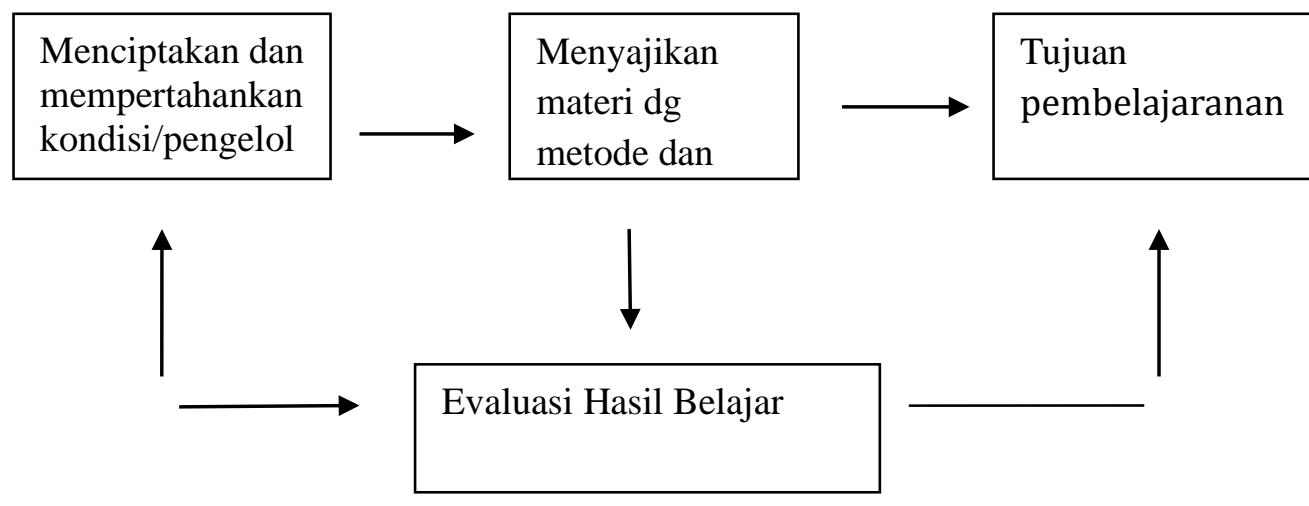

${ }^{14}$ Muljani A Nurhadi, 1983, Administrasi Pendidikan di Sekolah, Yogyakarta, Andi Offset, halaman 162

${ }^{15}$ Amatembun, NA. 1989. Manajemen Kelas, Penuntun Bagi Guru dan Calon Guru. Bandung, FIP IKIP Bandung, halaman 22

${ }^{16}$ Usman, M.U, 2003, Menjadi Guru Profesional, Bandung, Remaja Rosdakarya, halaman 97 
Diagram diatas menunjukkan bahwa:

Pengelolaan kelas bukan untuk secara langsung mencapai tujuan pembelajaran, melainkan agar pengelolaan pembelajaran dapat berlangsung dengan baik sehingga tujuan pembelajaran dapat tercapai

Pengelolaan kelas juga diperlukan agar kegiatan evaluasi hasil belajar dapat berlangsung dengan baik

Tindakan-tindakan pengelolaan kelas tidak hanya diperlukan pada awal kegiatan pembelajaran maupun awal pelaksanaan evaluasi hasil belajar, melainkan dapat dilakukan sepanjang pembelajaran maupun sepanjang evaluasi hasil belajar, bila memang diperlukan

\section{Tujuan Pengelolaan Kelas}

Pengelolaan kelas yang dilakukan guru bukan tanpa tujuan. Guru sadar tanpa mengelola kelas dengan baik, maka akan menghambat kegiatan belajar mengajarnya. Itu sama saja membiarkan pembelajaran tanpa membawa hasil, yaitu mengantarkan peserta didik dari tidak tahu menjadi tahu, dari tidak mengerti menjadi mengerti, dan dari tidak berilmu menjadi berilmu.

Secara umum tujuan pengelolaan kelas adalah untuk menciptakan suasana kelas yang nyaman untuk tempat berlangsungnya kegiatan pembelajaran. Dengan demikian, kegiatan tersebut akan dapat berjalan dengan efektif dan terarah, sehingga cita-cita pendidikand dapat tercapai demi terbentuknya sumber daya manusia yang berkualitas

Tujuan pengelolaan kelas pada hakikatnya telah terkandung dalam tujuan pendidikan. Secara umum tujuan pengelolaan kelas adalah penyediaan fasilitas bagi bermacam-macam kegiatan belajar peserta didik dalam lingkungan sosial, emosional dan intelektual dalam kelas. Fasilitas yang disediakan itu memungkinkan peserta didik belajar dan bekerja, terciptanya suasana sosial yang memberikan kepuasan, suasan disiplin, perkembangan intelektual, emosional, dan sikap serta apresiasi pada peserta $\operatorname{didik}^{17}$

${ }^{17}$ Sudirman, Op Cit, halaman 311 
Suharsimi Arikunto berpendapat bahwa tujuan pengelolaan kelas adalah agar setiap anak di kelas dapat bekerja dengan tertib sehingga segera tercapai tujuan pembelajaran secara efektif dan efisien. Menurutnya, sebagai indikator dari sebuah kelas yang tertib adalah apabila:

A. Setiap anak terus bekerja, tidak macet, artinya tidak ada anak yang terhenti karena tidak tahu ada tugas yang harus dilakukan atau tidak dapat melakukan tugas yang diberikan kepadanya

B. Setiap anak terus melakukan pekerjaan tanpa membuang waktu, artinya setiap anak akan bekerja secepatnya supaya lekas menyelesaikan tugas yang diberikan kepadanya. Apabila ada anak yang walaupun tahu dan dapat melaksanakan tugasnya, tetapi mengerjakannya kurang bergairah dan mengulur waktu bekerja, maka kelas tersebut dikatakan tidak tertib

Jadi beda antara (1) dan (2) adalah pada : (1) anak tidak tahu akan tugas atau tidak dapat melakukan tugas, dan pada (2) anak tahu dan dapat, tetapi kurang bergairah bekerja. Dengan kata lain, indicator keberhasilan dari kegiatan pengelolaan kelas adalah : (a) Bila sesudah itu setiap anak mampu untuk terus belajar dan bekerja. Peserta didik tidak mudah menyerah menyerah danpasif manakala mereka merasa tidak tahu atau kurang memahami tugas yang harus dikerjakan. Setidaknya, peserta didik maih menunjukkan semangat dan gairahnya untuk terus mencoba dan belajar, meski mereka menghadapi hambatan dan problem yang sulit sekalipun; dan (b) Bila setiap peserta didik mampu untuk terus melakukan pekerjaan tanpa membuang-buang waktu dengan percuma; artinya setiap peserta didik akan bekerja secepatnya supaya ia segera dapat menyelesaikan tugas yang diberikan kepadanya. Hal ini akan membuat peserta didik mampu mempergunakan waktu belajarnya seefektif dan seefisien mungkin

Jadi tujuan pengelolaan kelas adalah:

Mewujudkan situasi dan kondisi kelas, baik sebagai lingkungan belajar maupun sebagai kelompok belajar yang memungkinkan siswa untuk mengembangkan kemampuan semaksimal mungkin. 
Menghilangkan berbagai hambatan yang dapat menghalangi terwujudnya interaksi belajar mengajar.

Menyediakan dan mengatur fasilitas serta perabot belajar yang mendukung dan memungkinkan siswa belajar sesuai dengan lingkungan sosial, emosional, dan intelektual siswa dalam kelas.

Membina dan membimbing sesuai dengan latar belakang sosial, ekonomi, budaya serta sifat-sifat individunya

Dengan singkat dikatakan bahwa tujuan pengelolaan kelas adalah untuk menciptakan proses pembelajaran yang efektif sesuai dengan tujuan yang hendak dicapai

\section{Pendekatan Pengelolaan Kelas}

Keharmonisan hubungan guru dengan peserta didik, tingginya kerja sama diantara peserta didik tersimpul dalam bentuk interaksi. Karena itu there are many forms of interaction between teacher and pupils, and between pupils ${ }^{18}$ Lahirnya interaksi yang optimal tentu saja bergantung dari pendekatan yang guru lakukan dalam rangka pengelolaan kelas agar pembelajaran menjadi efektif. Menurut Syaiful Bahri ${ }^{19}$, pendekatan tersebut meliputi pendekatan kekuasaan, pendekatan ancaman, pendekatan kebebasan, pendekatan resep, pendekatan pembelajaran, pendekatan perubahan tingkah laku, pendekatan suasana emosi dan hubungan social, pendekatan proses kelompok dan pendekatan elektis atau pluralistic. Lebih jelasnya sebagai berikut:

\section{Pendekatan Kekuasaan}

Pengelolaan kelas diartikan sebagai suatu proses untuk mengontrol tingkah laku peserta didik. Peranan guru disini adalah menciptkan dan mempertahankan situasi disiplin kelas. Kesisiplinan adalah kekuatan yang menuntut kepada peserta didik untuk menaatinya. Didalamnya ada kekuasaan dalam norma yang mengikat untuk ditaati anggota kelas. Melalui kekuasaan dalam bentuk norma itulah guru mendekatinya

Didalam kegiatan pembelajaran, factor kedisiplinan adalah kekuatan utama untuk dapat menciptakan suasana belajar yang kondusif, karena itu guru perlu

18 Oscar.A.Oeser, 1966, Teacher Pupil and Task / Elements of Sosial Psychologi Applied to Education, Associated Book Publishers Limited II New Fetter Lane, London BCA, halaman 52

19 Syaiful Bahri Djamarah, 2006, Strategi Belajar Mengajar, Jakarta, , PT Rineka Cipta, halaman 179 
menekankan pentingnya peserta didik untuk menaati peraturan yang telah dibuat sebelumnya. Berbagai peraturan itu ibaratnya adalah "penguasa" yang wajib untuk ditaati. Oleh sebab itu, guru harus mampu melakukan pendekatan yang baik kepada peserta didik melalui peraturan ini, dan bukan kemauannya sendiri. ${ }^{20}$

Alangkah lebih baik jika sebelum memulai mengajar, guru membuat kesepakatan-kesepakatan dengan peserta didik mengenai keharusan untuk menaati aturan. Namun, tak hanya peserta didik, guru juga harus konsisten mengikuti segala peraturan yang ditetapkan agar tidak timbul kecemburuan diantara para peserta didik

\section{Pendekatan Ancaman}

Dari pendekatan ancaman atau intimidasi ini, pengelolaan kelas adalah juga sebagai suatu proses untuk mengontrol tingkah laku peserta didik. Tetapi dalam mengontrol tingkah laku peserta didik dilakukan dengan cara memberikan ancaman, misalnya melarang, ejekan, sindiran, dan memaksa.

Salman Rusydi menambahkan bahwa ancaman disini sepatutnya tidak dilakukan sesering mungkin dan hanya diterapkan manakala kondisi kelas sudah benar-benar tidk dapat dikendalikan. Selama guru masih mampu melakukan pendekatan lain di luar ancaman, maka akan lebih baik jika pendekatan dengan ancaman ini ditangguhkan ${ }^{21}$ Namun satu hal yang harus diingat, pendekatan ancaman harus dilakukan dalam taraf kewajaran dan diusahakan untuk tidak melukai perasaan peserta didik.

Guru mungkin perlu memberi ancaman seperti penangguhan nilai, pemberian tugas tambahan, serta memberikan tugas-tugas lain yang sifatnya mendidik bagi mereka. Ancaman dalam bentuk intimidasi yang berlebihan, seperti mengejek, membanding-bandingkan, memukul dan memaksa, sebaiknya difikirkan ulang sebelum diterapkan. Sebab ancaman seperti itu sangat mungkin dapat melukai perasaan peserta didik serta menyebabkan mereka semakin bertindak represif didalam kelas. Sindiran halus juga dapat dilakukan oleh guru terhadap peserta didik yang kurang menaati aturan.

${ }^{20}$ Salman Rusydi, Op Cit, halaman 49

${ }^{21}$ Salman Rusydi, ibid, halaman 50 


\section{Pendekatan Kebebasan}

Pengelolaan diartikan sebagai suatu proses untuk membantu peserta didik agar merasa bebas untuk mengerjakan sesuatu kapan saja dan dimana saja. Peranan guru adalah mengusahakan semaksimal mungkin kebebasan peserta didik, selama hal itu tidak menyimpang dari peraturan yang telah ditetapkan dan disepakati bersama. Terkadang, peserta didik tidak nyaman apabila ada seoran guru yang terlalu overprotectif sehingga peserta didik tidak leluasa melakukan eksperimennya

Jika kita memberikan tugas kepada peserta didik untuk menuliskan beberapa pengalaman, maka berilah mereka kebebasan untuk menceritakan apa saja yang mereka tuliskan. Jangan terlalu membuat ketentuan-ketentuan terlalu ketat yang karenanya dapat mengekang kebebasan peserta didik untuk mengembangkan imajinasi dan kreativitasnya

\section{Pendekatan Resep}

Pendekatan resep (cook book) ini dilakukan dengan memberi satu daftar yang dapat menggambarkan apa yang harus dan apa yang tidak boleh dikerjakan oleh guru dalam mereaksi semua masalah atau situasi yang terjadi di kelas. Dalam daftar ini digambarkan tahap demi tahap apa yang harus dikerjakan oleh guru. Peranan guru hanyalah mengikuti petunjuk seperti yang tertulis dalam resep ${ }^{22}$

Tidak ada salahnya apabila guru juga meminta peserta didik untuk mengemukakan hal-hal yang kurang mereka sukai dari cara kita mengajar serta apa yang mereka inginkan. Disamping itu, akan sangat baik jika kita meminta peserta didik untuk mengemukakan hal-hal yang mereka sukai dari kita. Semua komentar peserta didik hendaknya kita perhatikan baik-baik, untuk kemudian diaplikaikan dalam tindakan nyata.

\section{Pendekatan Pembelajaran}

Pendekatan ini didasarkan atas suatu anggapan bahwa dalam suatu perencanaan dan pelaksanaan akan mencegah munculnya masalah tingkah laku peserta didik, dan memecahkan masalah itu bila tidak bisa dicegah. Pendekatan ini menganjurkan tingkah laku guru dalam mengajar untuk mencegah dan menghentikan tingkah laku

${ }^{22}$ Saiful Bahri Djamarah, Op Cit, halaman 180 
peserta didik yang kurang baik. Peranan guru adalah merencanakan dan mengimplementasikan pelajaran yang baik.

Karena itu buatlah perencanaan pembelajaran yang matang sebelum kita masuk kelas dan patuhilah tahapan-tahapan yang sudah kita buat sebelumnya. Hindari kebiasaan mengajar dengan apa adanya, apalagi tanpa perencanaan yang matang. Pembelajaran yang dilakukan secara sistematis tentu dapat membuat peserta didik terhindar dari kejenuhan, karena mereka dapat mengikuti pelajarannya secara bertahap. Sebaliknya peserta didik akan cepat lelah apabila mereka tidak faham alur pembelajaran yang disampaikan gurunya, sehingga materi yang mereka pelajari cenderung membingungkan.

\section{Pendekatan Perubahan Tingkah Laku}

Sebagaimana prinsipnya, pengelolaan kelas diartikan sebagai suatu proses untuk mengubah tingkah laku peserta didik dari yang kurang baik menjadi baik.. Pendekatan berdasarkan perubahan tingkah laku (behavior modivication approach) ini bertolak dari sudut pandangan Psikologi Behavioral yang mengemukakan asumsi sebagai berikut:

a. Semua tingkah laku yang baik dan yang kurang baik merupakan hasil proses belajar. Asumsi ini mengharuskan wali/guru kelas berusaha menyusun program kelas dan suasana yang dapat merangsang terwujudnya proses belajar yang memungkinkan peserta didik mewujudkan tingkah laku yang baik menurut ukuran norma yang berlaku di lingkungan sekitarnya.

b. Didalam proses belajar terdapat proses psikologis yang fundamental berupa penguatan positif (positive reinforcement), hukuman, penghapusan (extenction) dan penguatan negative (negative reinformcement). Asumsi ini mengharuskan seorang wali/guru kelas melakukan usaha-usaha mengulang-ulangi program atau kegiatan yang dinilai baik (perangsang) bagi terbentuknya tingkah laku tertentu, terutama di kalangan peserta didik.

Kegiatan itu akan menjadi penguatan positif sehingga tujuan yang dirumuskan lebih mudah dicapai. Sebaliknya, program atau kegiatan yang mengakibatkan timbulnya tingkah laku yang kurang baik, harus diusahakan menghindarinya sebagai 
kurang baik, harus diusahakan menghindarinya sebagai penguatan negative yang pada suatu saat akan hilang dari tingkah laku peserta didik atau guru yang menjadi anggota kelasnya.

Untuk itu, menurut pendekatan tingkah laku yang baik atau positif harus dirangsang dengan memberikan pujian atau hadiah yang menimbulkan perasaan senang atau puas. Sebaliknya, tingkah laku yang kurang baik dalam melaksanakan program kelas harus diberi sanksi atau hukuman yang akan menimbulkan perasaan tidak puas dan pada gilirannya tingkah laku tersebut akan dihindari ${ }^{23}$.Namun demikian agar pelaksanaan hukuman berjalan efektif dan cukup manusiawi maka perlu diperhatikan hal-hal sebagai berikut: (1)Gunakan hukuman secara ketat/terbatas dan seperlunya (tidak royal),(2) Jelaskan kepada peserta didik kenapa ia memperoleh hukuman seperti itu, (3) Sediakan pula jalan alternatif bagi peserta didik dalam memperoleh penguatan (untuk menjauhi hukuman),(4) Berikan penguatan dan hukuman secara proporsional, misal beri hukuman ketika peserta didik tidak menyelesaikan tugas sementara itu beri penguatan ketika siswa berhasil melaksanakan tugasnya, (5) Hindari bentuk-bentuk hukuman fisik,(6) Sesegeralah memberikan hukuman sewaktu perilaku menyimpang tersebut mulai terjadi, jangan dibiarkan terlalu lama baru diberikan hukuman

\section{Pendekatan Suasana Emosi dan Hubungan Sosial}

Pendekatan pengelolaan kelas berdasarkan suasana perasaan dan suasana social (socio-emotional climate approach) didalam kelas sebagai kelompok individu cenderung pada pandangan psikologi klinis dan konseling (penyuluhan). Menurut pendekatan ini pengelolaan kelas merupakan suatu proses menciptakan iklim atau suasana emosional dan hubungan social yang positif dalam kelas.

Suasana emosional dan hubungan social yang positif, artinya ada hubungan yang baik dan positif antara guru dengan peserta didik, atau antara peserta didik dengan peserta didik. Disini guru adalah kunci terhadap pembentukan hubungan pribadi itu, dan peranannya adalah menciptakan hubungan pribadi yang sehat. Untuk itu terdapat dua asumsi pokok yang dipergunakan dalam pengelolaan kelas sebagai berikut:

${ }^{23}$ Syaiful Bahri Djamarah, Op Cit, halaman 181 
a. Iklim social dan emosional yang baik adalah dalam arti terdapat hubungnn interpersonal yang harmonis antara guru dengan guru, guru dengan peserta didik, dan peserta didik dengan peserta didik, merupakan kondisi yang memungkinkan berlangsungnya kegiatan pembelajaran yang efektif. Asumsi ini mengharuskan seorang wali/guru kelas berusaha menyusun program kelas dan pelaksanannya yang didasari oleh hubungan manusiawi yang diwarnai sikap saling menghargai dan saling menghormati antar personal di kelas. Setiap personal diberi kesempatan untuk ikut serta dalam kegiatan kelas sesuai dengan kesempatan untuk ikut serta dalam kegiatan kelas sesuai dengan kemampuan masing-masing, sehingga timbul suasana social dan emosional yang menyenangkan pada setiap personal dalam melaksanakan tugas dan tanggung jawab masing-masing.

b. Iklim social yang emosional yang baik tergantung pada guru dalam usahanya melaksanakan kegiatan pembelajaran, yang disadari dengan hubungan manusiawi yang efektif. Dari asumsi ini berarti dalam pengelolaan kelas seorang wali/guru kelas harus berusaha mendorong guru-guru agar mampu dan bersedia mewujudkan hubungan manusiawi yang penuh saling pengertian, hormat menghormati dan saling menghargai. Guru harus didorong menjadi pelaksana yang berinisiatif dan kreatif serta selalu terbuka pada kritik. Disamping itu, berarti guru harus mampu dan bersedia mendengarkan pendapat, saran, gagasan, dan lain-laian dari peserta didik sehigga pengelolaan kelas berlangsung dinamis

\section{Pendekatan Proses Kelompok}

Pendekatan kerja kelompok dengan model ini membutuhkan kemampun guru dalam menciptakan momentum yang dapat mendorong kelompok-kelompok didalam kelas menjadi kelompok yang produktif. Disamping itu, pendektan ini jug mengharuskan guru untuk memapu menjaga kondisi hubungan antar kelompok agar dapat selalu berjalan dengan baik ${ }^{24}$.. Menurut Syaiful Bahri Djamarah ${ }^{25}$, dasar dari Group Process Approach ini adalah psikologi social dan dinamis kelompok yang mengetengahkan dua asumsi sebagai berikut:

${ }^{24}$ Salman Rusydi, Op Cit, halaman 55

25 Syaiful Bahri Djamarah, Op Cit, halaman 182 
a. Pengalaman belajar di sekolah bagi peserta didik berlangsung dalam konteks kelompok social. Asumsi ini mengharuskan wali/guru kelas dalam pengelolaan kelas selalu mengutamakan kegiatan yang dapat mengikutsertakan seluruh personal di kelas. Dengan kata lain, kegiatan kelas harus diarahkan pada kepentingan bersama dan sedikit mungkin kegiatan yang bersifat individual.

b. Tugas guru terutama adalah memelihara kelompok belajar agar menjadi kelompok yang efektif dan produktif. Berdasarkan asumsi ini berarti seorang wali/guru kelas harus mampu membentuk dan mengaktifkan peserta didik bekerja sama dalam kelompok (group studies). Hal tersebut harus dilaksanakan secara efektif agar hasilnya lebih baik daripada peserta didik belajar sehari-hari (produktif). Kegiatan guru sebagai kelompok antara lain dapat diwujudkan berupa regu belajar (team teaching) yang bertugas membantu kelompok belajar.

\section{Pendekatan Elektis atau Pluralistik}

Pendekatan elektis (electic approach) ini menekankan pada potensialitas, kreativitas, dan inisiatif wali/guru kelas dalam memilih berbagai pendekatan itu dalam suatu situasi mungkin dipergunakan salah satu dan dalam situasi lain mungkin harus mengombinasikan dan atau ketiga pendekatan tersebut. Pendekatan elektis disebut juga pendekatan pluralistic, yaitu pengelolaan kelas yang berusaha menggunakan berbagai macam pendekatan yang memiliki potensi untuk dapat menciptakan dan mempertahankan suatu kondisi yang memungkinkan kegiatan pembelajaran berjalan efektif dan efisien. ${ }^{26}$

Dari beberapa pendekatan diatas, guru bebas memilih dan menggabungkan berbagai pendekatan sesuai dengan kemampuannya untuk menumbuhkan kegiatan pembelajaran yang efektif

\section{Kesimpulan}

Dari uraian diatas dapat disimpulkan bahwa pengelolaan kelas adalah suatu usaha guru untuk menciptakan suasana kegiatan belajar mengajar yang kondusif agar tercapai kondisi yang optimal sesuai dengan yang diharapkan dan mengendalikannya apabila terjadi gangguan dalam pembelajaran.. Atau dengan kata lain pengelolaan kelas merupakan kegiatan pengaturan kelas untuk kepentingan pembelajaran. Adapun 
pendekatan dalam pengelolaan kelas agar pembelajaran menjadi efektif meliputi: pendekatan kekuasaan, pendekatan ancaman, pendekatan kebebasan, pendekatan resep, pendekatan pembelajaran, pendekatan perubahan tingkah laku, pendekatan suasana emosi dan hubungan social, pendekatan proses kelompok dan pendekatan elektis atau pluralistic

\section{DAFTAR PUSTAKA}

AJE Toenlioe, 1991, Teori dan Praktek Pengelolaan Kelas, Surabaya, Usaha Nasional

Amatembun, NA. 1989. Manajemen Kelas, Penuntun Bagi Guru dan Calon Guru. Bandung, FIP IKIP Bandung

E.Mulyasa, 2005, Menjadi Guru Profesional, Bandung: Rosda Karya

Hadari Nawawi, 1989, Organisasi Sekolah dan Pengelolaan Kelas, Jakarta, Haji Masagung

Made Pidarta, tt, Pengelolaan Kelas, Surabaya, Usaha Nasional

Muljani A Nurhadi, 1983, Administrasi Pendidikan di Sekolah, Yogyakarta, Andi Offset

Oemar Hamalik, 1987, Pendekatan Baru Strategi Belajar Mengajar Berdasarkan CBSA, Bandung, Sinar Baru

Oscar.A.Oeser, 1966, Teacher Pupil and Task / Elements of Sosial Psychologi Applied to Education, Associated Book Publishers Limited II New Fetter Lane, London B

Sudirman, 1991, Ilmu Pendidikan, Bandung, Remaja Rosdakarya

Suharsimi Arikunto, 1990, Manajemen Pengajaran Secara Manusiawi, Jakarta, Rineka Cipta

Suharsimi Arikunto, 1988,Pengelolaan Kelas dan Siswa Sebuah Pendekatan Evaluatif, Jakarta, Rajawali Press

Syaifurahman, 2013, Manajemen dalam Pembelajaran, Jakarta, PT Indeks

Syaiful Bahri Djamarah, 2006, Strategi Belajar Mengajar, Jakarta, , PT Rineka Cipta

Usman, M.U, 2003, Menjadi Guru Profesional, Bandung, Remaja Rosdakarya

http://carapedia.com, diunduh tanggal 19 Mei 2015 